\title{
The risk of second primary tumors in head and neck cancer: A systematic review
}

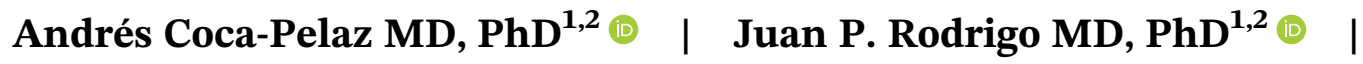 \\ Carlos Suárez MD, $\mathbf{P h D}^{2} \quad$ Iain J. Nixon MD, MBChB, FRCS (ORL-HNS), $\mathbf{P h D}^{\mathbf{3}}$ ｜ \\ Antti Mäkitie MD, $\mathbf{P h D}^{4}$ | Alvaro Sanabria $\mathbf{M S c}, \mathbf{P h D}^{\mathbf{5}}$ ( ) |

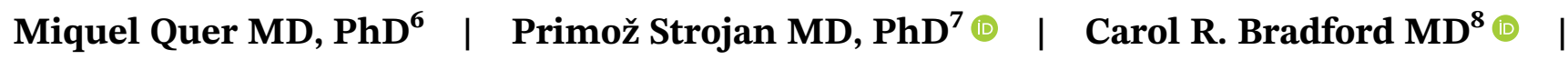 \\ Luiz P. Kowalski MD, PhD $^{9} \quad$ | Ashok R. Shaha MD $^{10} \odot$ | \\ Remco de Bree MD, $\mathbf{P h D}^{11}$ ( ) | Dana M. Hartl MD, $\mathbf{P h D}^{12,13}$ |
}

Alessandra Rinaldo MD, FRCSEd ad hominem, FRCS (Eng, Ir) ad eundem, FRCSGlasg ${ }^{14}$ ।

Robert P. Takes MD, PhD ${ }^{15}$ ( ) | Alfio Ferlito MD, DLO, DPath, FRCSEd ad

hominem, FRCS (Eng, Glasg, Ir) ad eundem, FDSRCS ad eundem, FHKCORL, FRCPath, FASCP, IFCAP ${ }^{16}$

\footnotetext{
${ }^{1}$ Department of Otolaryngology, Hospital Universitario Central de Asturias-University of Oviedo, Oviedo, Spain

${ }^{2}$ Instituto de Investigación Sanitaria del Principado de Asturias, IUOPA, CIBERONC, Oviedo, Spain

${ }^{3}$ Ear, Nose and Throat Department, NHS Lothian, University of Edinburgh, Edinburgh, UK

${ }^{4}$ Department of Otorhinolaryngology, Head and Neck Surgery, University of Helsinki and Helsinki University Hospital, Helsinki, Finland

${ }^{5}$ Department of Surgery, School of Medicine, Universidad de Antioquia, CEXCA. Centro de Excelencia en Enfermedades de Cabeza y Cuello. Medellín, Colombia.

${ }^{6}$ Department of Otolaryngology, Hospital Santa Creu i Sant Pau, Barcelona, Spain

${ }^{7}$ Department of Radiation Oncology, Institute of Oncology, Ljubljana, Slovenia

${ }^{8}$ Department of Otolaryngology—Head and Neck Surgery, University of Michigan, Ann Arbor, Michigan

${ }^{9}$ Department of Head and Neck Surgery and Otorhinolaryngology, A.C. Camargo Cancer Center, Sao Paulo, Brazil

${ }^{10}$ Head and Neck Service, Memorial Sloan-Kettering Cancer Center, New York, New York

${ }^{11}$ Department of Head and Neck Surgical Oncology, University Medical Center Utrecht, Utrecht, The Netherlands

${ }^{12}$ Department of Otolaryngology—Head and Neck Surgery, Institut Gustave Roussy, Villejuif Cedex, France

${ }^{13}$ Laboratoire de Phonétique et de Phonologie, Paris, France

${ }^{14}$ University of Udine School of Medicine, Udine, Italy

${ }^{15}$ Department of Otolaryngology — Head and Neck Surgery, Radboud University Medical Center, Nijmegen, The Netherlands

${ }^{16}$ Coordinator of the International Head and Neck Scientific Group, Padua, Italy
}

\section{Correspondence}

Andrés Coca-Pelaz, Department of Otolaryngology, Hospital Universitario Central de Asturias, Avenida de Roma s/n, Oviedo 33011, Spain.

Email: acocapelaz@yahoo.es

Section Editor: Jose Zevallos

\section{Abstract}

Background: Second primary tumors (SPTs) are a common cause of reduced life expectancy in patients treated for head and neck cancer (HNC). This phenomenon forms an area to be addressed during posttreatment follow-up.

This article was written by members of the International Head and Neck Scientific Group (www.IHNSG.com). 
Methods: We conducted a systematic review of literature following PRISMA guidelines, from 1979 to 2019, to investigate incidence of SPTs, synchronous, and metachronous, in HNC population.

Results: Our review includes data of 456130 patients from 61 articles. With a minimum follow-up of 22 months, mean incidence of SPTs was $13.2 \%$ (95\% CI: 11.56-14.84): 5.3\% (95\% CI: 4.24-6.36) for synchronous SPTs and 9.4\% (95\% CI: 7.9-10.9) for metachronous SPTs. The most frequent site for SPTs was head and neck area, followed by the lungs and esophagus.

Conclusion: Although with wide variations between studies, the rate of SPTs in HNC patients is high. Given the impact in the prognosis, we must develop strategies for the early diagnosis of SPTs.

\section{K E Y W O R D S}

head and neck cancer, metachronous, second primary tumor, squamous cell carcinoma, synchronous

\section{1 | INTRODUCTION}

Head and neck cancers (HNCs) are the sixth most common malignancy worldwide. Approximately two thirds of HNC patients present with locally advanced disease. ${ }^{1}$ The survival rates for early stage disease are high, but despite advances in treatment options, about $40 \%$ of locally advanced cases will recur after front-line treatment. More than $50 \%$ of these patients will develop a loco-regional recurrence within 2 years, and a $20 \%$ to $30 \%$ of those patients will develop distant metastases. ${ }^{2}$ In contrast, most HNC patients are tobacco and alcohol consumers who have a significant risk of second primary tumors (SPTs), which may be detected either at the point of diagnosis or during follow-up. ${ }^{3}$ SPTs are a major cause of mortality in HNC survivors. ${ }^{4-6}$ It is postulated that this phenomenon is the result of "field cancerization" which denotes the entire aerodigestive epithelium having been exposed to chronic carcinogenic insults and is therefore predisposed to develop multiple premalignant and malignant lesions. ${ }^{7}$ The SPT risk is about $2 \%$ to $4 \%$ per year, a rate of about $10 \%$ to $20 \%$ overall lifetime risk. ${ }^{1,8}$

The complexity of organizing follow-up for HNC patients includes the technical expertise required (e.g., flexible naso-laryngoscopic examination, imaging studies), the comorbidities experienced by the patients and the psychofunctional disruptions caused by both the disease and treatment. ${ }^{9}$ The main objectives of follow-up in HNC is the evaluation of clinical response and adverse effects of treatment, the early detection of a recurrence or SPTs and the restoration of the patient to their premorbid health status to the maximal extent possible. ${ }^{2}$ In general, a HNC surveillance program must consider several aspects: the index disease recurrence rate, the optimal method for monitoring, and whether earlier detection of recurrence has the potential to result in successful salvage treatment and/or improved survival. ${ }^{10}$

Two important factors that should be considered: first, the influence of persistent tobacco and alcohol use on the risk of SPTs in the aerodigestive tract, and second, the differences between HPV-positive patients and negative patients in terms of SPT incidence. For example, Leon et $\mathrm{al}^{11}$ carried out a matched case-control study in 514 patients with HNC and found that the odds ratio of SPT for patients who continued to smoke was 2.9 and for patients who continued to use alcohol it was 5.2. With respect to HPV status, it has been reported that patients with HPV-positive oropharyngeal cancer have a lower risk of appearance of SPTs than HPVnegative patients, particularly in those locations related to tobacco use or alcohol consumption. ${ }^{12}$ Thus, Morris et $\mathrm{al}^{13}$ reviewed 75087 patients with $\mathrm{HNC}$ and found that before the 1990s, hypopharynx and oropharynx cancers carried the highest risk of SPT, since then, during the HPV era, SPT risk associated with oropharyngeal cancer has declined to the lowest risk level of any subsite. A recent retrospective study in a large cohort of HNC patients also showed that patients with HPV-related tumors has a lower risk of development of SPTs. ${ }^{14}$

This review aims at defining the average rate for SPTs in HNC patient population and the pattern of synchronous and metachronous tumors.

In order to evaluate the incidence of SPT on the longterm follow-up of the HNC patients, we performed a review of relevant articles on this issue. 


\section{2 | PATIENTS AND METHODS}

The Preferred Reporting Items for Systematic Review and Meta-Analyses (PRISMA) method was used to conduct a systematic review of the current literature. ${ }^{15}$ The search strategy aimed to include articles concerning the development of SPTs in patients treated for HNC. A PubMed internet search updated to April 1, 2019 was performed for English language publications between the years 1979 and 2019 using the following search criteria in the title or abstract: "head and neck cancer," coupled with "second primary cancer" or "second primary tumor" or "second primary malignancy", "metachronous" and "synchronous." The search results were reviewed for potentially eligible studies. When there was any information in the abstract about the study addressing SPTs in HNC patients, the full text article was searched. All review articles were also checked in full. References from any full text articles were crosschecked to ensure inclusion of all relevant publications (Figure 1). Studies were selected if they met the following inclusion criteria: (a) patients treated for $\mathrm{HNC}$ (mucosal squamous cell carcinoma), (b) information on the percentage of SPTs in these patients, and (c) on the location of the SPTs is included in the text. Studies in which the percentage of SPTs was analyzed in patients with non-head and neck primary tumors, or when HNC data were analyzed together with primaries from other locations, were excluded. The same applied to articles in which only a specific type of SPT was analyzed. This last criterion was included because the objective of our study was to assess the incidence of all possible SPTs and not only in one location (e.g., lungs).

\section{3 | RESULTS}

Our search criteria identified, 5540 papers and after removal of duplicates, 61 papers were selected for data review and are summarized in Table $1 .^{5,6,16-74}$ Most of the studies were retrospective. Our review includes 456130 patients from these 61 articles during a period of 40 years (1979-2019). As can be seen in Table 1, data on the percentage of synchronous and metachronous tumors were not available in all articles, and some of them only reported the total percentage of SPTs. The mean rate of SPTs was $13.2 \%$ (95\% CI: 11.56-14.84)). The mean rate of synchronous SPTs was 5.3\% (95\% CI: 4.24-6.36). In the case of metachronous SPTs, with a minimum follow-up of 22 months in the included studies (range 22-252 months, median 55 months), the mean rate was 9.4\% (95\% CI: 7.9-10.9). The large difference in SPT rates observed in Table 1 could be explained by several reasons: there is great variability between the studies, in terms of the location of tumors, the characteristics of the patients, as well as the duration of follow-up (since the incidence is cumulative, the duration of the follow-up is critical and may explain much of the observed difference) and the diagnostic methods used to detect SPTs. In $24 \%$ of the studies panendoscopy was the method used to screen for SPTs and in 15\% some type of imaging test, but in $61 \%$ of them there is no data about

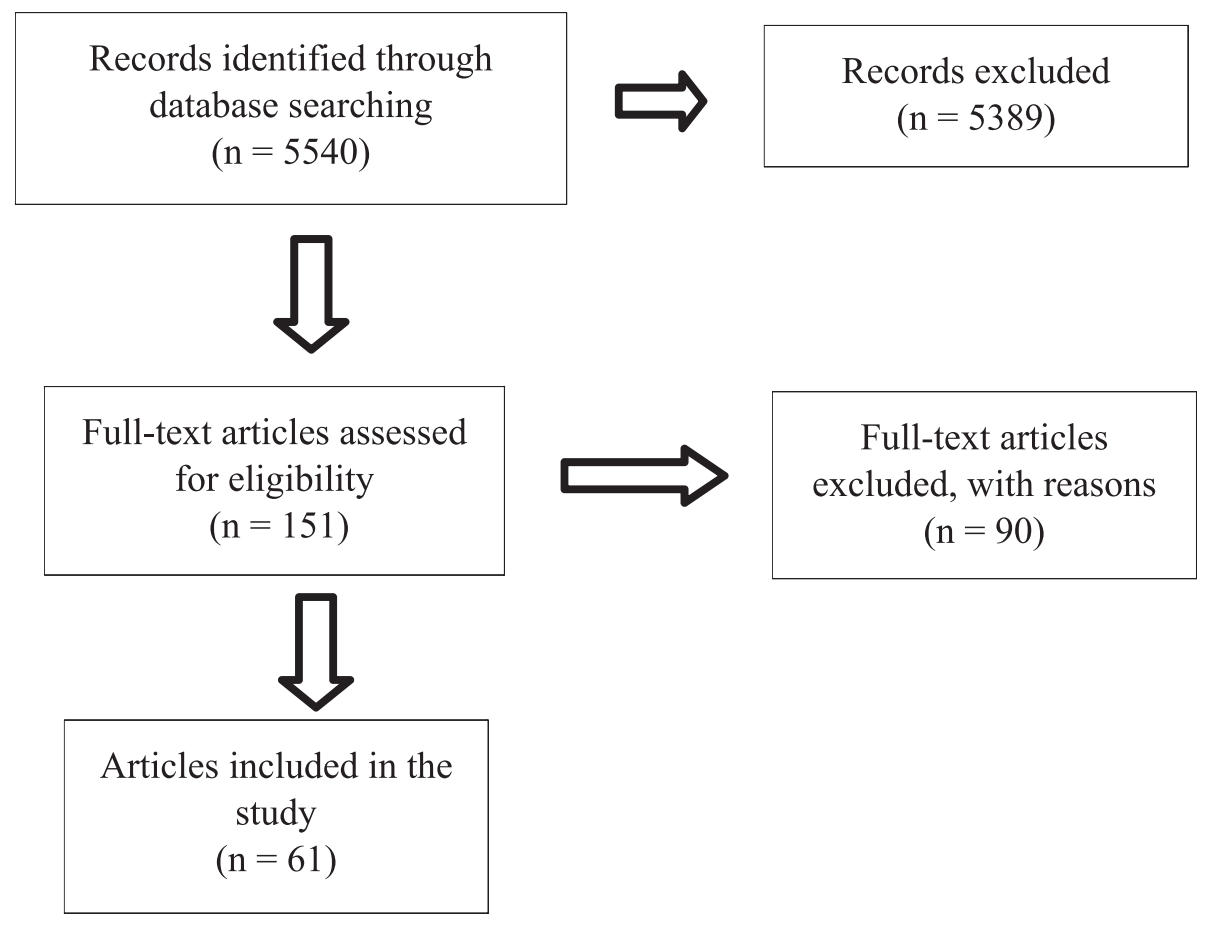

FIGURE 1 Flow chart showing the process of the study selection for the systematic review 
T A B L E 1 Compiled findings in selected series describing multiple primary tumors in the head and neck

\begin{tabular}{|c|c|c|c|c|c|c|c|}
\hline Reference & Year & $\begin{array}{l}\text { Number } \\
\text { of patients }\end{array}$ & Study & $\%$ of ST & $\%$ of MT & \% Total & Location of SPT \\
\hline Weichert and Schumrick ${ }^{16}$ & 1979 & 825 & $\mathrm{R}$ & 2.3 & 4.2 & 6,5 & $\begin{array}{l}\text { Head and neck, lung, } \\
\text { esophagus }\end{array}$ \\
\hline Vrabec $^{17}$ & 1979 & 1518 & $\mathrm{R}$ & 3.7 & 7.8 & 11.5 & $\begin{array}{l}\text { Head and neck, lung, } \\
\text { esophagus, other locations }\end{array}$ \\
\hline Shapshay et $\mathrm{al}^{20}$ & 1980 & 150 & $\mathrm{P}$ & 19 & NA & NA & Head and neck, esophagus \\
\hline Maisel and Vermeersch ${ }^{21}$ & 1981 & 449 & $\mathrm{R}$ & 8 & 4.7 & 12.7 & Lung, esophagus \\
\hline Atkinson et $\mathrm{al}^{22}$ & 1982 & 271 & $\mathrm{P}$ & 10.3 & NA & NA & $\begin{array}{l}\text { Head and neck, lung, } \\
\text { esophagus }\end{array}$ \\
\hline \multirow[t]{3}{*}{ Black et $\mathrm{al}^{25}$} & \multirow[t]{3}{*}{1983} & 645 & $\mathrm{P}$ & 8.9 & NA & NA & \multirow{3}{*}{$\begin{array}{l}\text { Head and neck, lung and other } \\
\text { locations }\end{array}$} \\
\hline & & 577 & $\mathrm{R}$ & 6.2 & 14.7 & 20.9 & \\
\hline & & 5337 & $\mathrm{R}$ & 5.1 & 8.7 & 13.8 & \\
\hline Grossman et $\mathrm{al}^{26}$ & 1983 & 696 & $\mathrm{P}$ & 5.4 & NA & NA & $\begin{array}{l}\text { Head and neck, lung, } \\
\text { esophagus }\end{array}$ \\
\hline Hordijk and de Jong ${ }^{27}$ & 1983 & 1148 & $\mathrm{R}$ and $\mathrm{P}$ & 2 & 15.5 & 17.5 & $\begin{array}{l}\text { Head and neck, lung and other } \\
\text { locations }\end{array}$ \\
\hline Atkins et $\mathrm{al}^{28}$ & 1984 & 451 & $\mathrm{R}$ & 2.5 & 5 & 7.5 & $\begin{array}{l}\text { Head and neck, lung, } \\
\text { esophagus, other locations }\end{array}$ \\
\hline Lundgren and Olofsson ${ }^{32}$ & 1986 & 295 & $\mathrm{R}$ & 1.4 & 11.2 & 12.6 & $\begin{array}{l}\text { Head and neck, lung, } \\
\text { esophagus }\end{array}$ \\
\hline Schuller and Fritsch ${ }^{33}$ & 1986 & 53 & $\mathrm{P}$ & 11.3 & NA & NA & Head and neck, lung \\
\hline Shikhani et $\mathrm{al}^{34}$ & 1986 & 1961 & $\mathrm{R}$ & 4.9 & 4.7 & 9.6 & Head and neck, esophagus \\
\hline Shibuya et $\mathrm{al}^{35}$ & 1987 & 1429 & $\mathrm{R}$ & 2.3 & 7.2 & 9.5 & Head and neck, digestive tract \\
\hline Masaki et $\mathrm{al}^{36}$ & 1987 & 3162 & $\mathrm{R}$ & 1.2 & 7.1 & 8.3 & $\begin{array}{l}\text { Head and neck, digestive tract, } \\
\text { lung }\end{array}$ \\
\hline Poppendieck ${ }^{37}$ & 1987 & 589 & $\mathrm{P}$ & 3.05 & 3.4 & 6.45 & $\begin{array}{l}\text { Head and neck. esophagus, } \\
\text { lung }\end{array}$ \\
\hline Parker and $\mathrm{Hill}^{38}$ & 1988 & 208 & $\mathrm{P}$ & 7.2 & NA & NA & Head and neck, lung \\
\hline Poppendieck and Schrader ${ }^{39}$ & 1988 & 712 & $\mathrm{R}$ & 7.1 & 7.9 & 15 & $\begin{array}{l}\text { Head and neck. esophagus, } \\
\text { lung }\end{array}$ \\
\hline Shaha et $\mathrm{al}^{40}$ & 1988 & 140 & $\mathrm{P}$ & 13 & NA & NA & $\begin{array}{l}\text { Head and neck. esophagus, } \\
\text { lung }\end{array}$ \\
\hline Hordijk et al ${ }^{41}$ & 1989 & 141 & $\mathrm{P}$ & 1.4 & NA & NA & Head and neck, lung \\
\hline Panosetti et al ${ }^{42}$ & 1989 & 9089 & $\mathrm{R}$ & 3.9 & 5.3 & 9.2 & $\begin{array}{l}\text { Head and neck, Esophagus, } \\
\text { lung }\end{array}$ \\
\hline
\end{tabular}


T A B LE 1 (Continued)

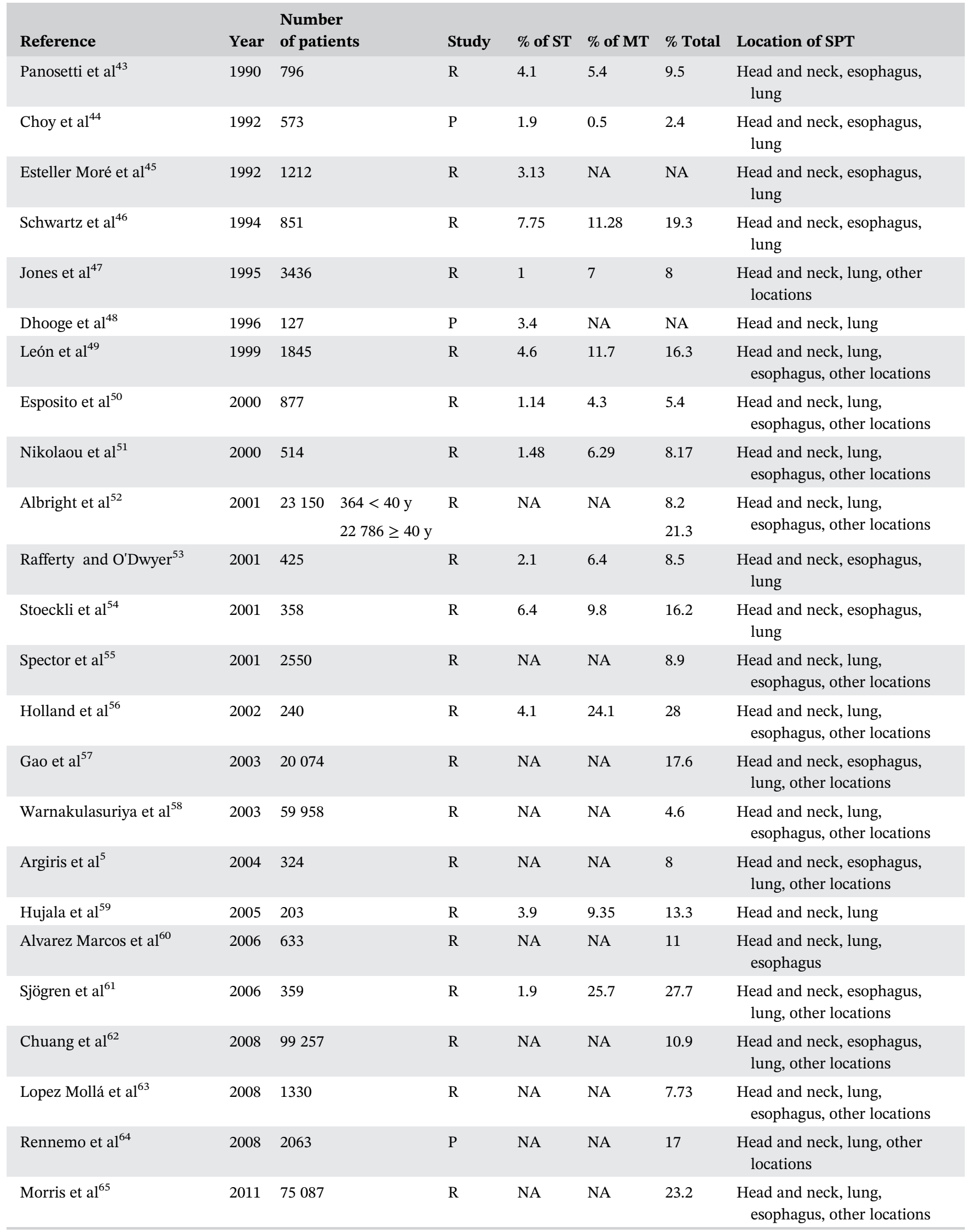


T A B L E 1 (Continued)

\begin{tabular}{|c|c|c|c|c|c|c|c|}
\hline Reference & Year & $\begin{array}{l}\text { Number } \\
\text { of patients }\end{array}$ & Study & $\%$ of ST & $\%$ of MT & \% Total & Location of SPT \\
\hline Rodriguez-Bruno et $\mathrm{al}^{66}$ & 2011 & 64 & $\mathrm{R}$ & 6.25 & NA & NA & Head and Neck \\
\hline Krishnatreya et al ${ }^{68}$ & 2013 & 4184 & $\mathrm{R}$ & 1.3 & NA & NA & $\begin{array}{l}\text { Head and neck, esophagus, } \\
\text { lung }\end{array}$ \\
\hline Tiwana et $\mathrm{al}^{69}$ & 2014 & 1658 & $\mathrm{R}$ & 3 & 24 & 27 & $\begin{array}{l}\text { Head and neck, lung, } \\
\text { esophagus, other locations }\end{array}$ \\
\hline Patrucco and Aramendi ${ }^{70}$ & 2016 & 307 & $\mathrm{R}$ & 0.32 & 8.46 & 8.79 & $\begin{array}{l}\text { Head and neck, lung, } \\
\text { esophagus, other locations }\end{array}$ \\
\hline Adjei Boakye et al ${ }^{72}$ & 2018 & 109512 & $\mathrm{R}$ & NA & NA & 12.3 & $\begin{array}{l}\text { Head and neck, lung, } \\
\text { esophagus, other locations }\end{array}$ \\
\hline Leoncini et $\mathrm{al}^{73}$ & 2018 & 4005 & $\mathrm{R}$ & NA & NA & 8.6 & $\begin{array}{l}\text { Head and neck, lung, other } \\
\text { locations }\end{array}$ \\
\hline Silén et $\mathrm{al}^{74}$ & 2019 & 151 & $\mathrm{R}$ & NA & NA & 26 & $\begin{array}{l}\text { Head and neck, lung, } \\
\text { esophagus, other locations }\end{array}$ \\
\hline
\end{tabular}

Abbreviations: MT, metachronous tumor; NA, not available; P, prospective; R, retrospective; SPT, second primary tumor; ST, synchronous tumor.

T A B L E 2 Analysis of the significant differences in Table 1

\begin{tabular}{|c|c|c|c|c|c|c|}
\hline Data & & Number of patients & Mean \% ST & Mean \% MT & $\%$ Total & Median follow-up (y) \\
\hline \multirow[t]{2}{*}{ By years } & 1979-1998 & 39586 & 6 & 7.6 & 11.1 & 3.2 \\
\hline & 1999-2019 & 420107 & 3.3 & 12.5 & 14.8 & 5 \\
\hline By type of study & $\mathrm{P}$ & 7679 & 8.5 & 6.5 & 10.8 & 2.6 \\
\hline Global & & 456130 & 5.3 & 9.4 & 13.2 & 4.6 \\
\hline
\end{tabular}

Abbreviations: MT, metachronous tumor; P, prospective; R, retrospective; ST, synchronous tumor.

which tests were used to diagnose SPTs. In several studies, a hospital or regional tumor registry was used for the collection of the data, which explains the large proportion of SPTs found outside the aerodigestive system, with the consequent higher rate compared with studies using panendoscopy alone. In order to extract more information on the data available, we divided them in different ways (Table 2). Studies were coded as prospective or retrospective, observing that the main bulk of patients were included in retrospective studies. A lower percentage of synchronous SPTs were observed in retrospective studies, $3.6 \%$, compared with $8.5 \%$ in prospective studies, but the overall percentage of SPTs was higher for retrospective studies (13.4\% vs $10.8 \%)$. The percentage of synchronous SPTs was higher in prospective studies, given that almost all studies in this group were conducted during the first two decades of the present review, that is, when the main diagnostic method used for diagnosing SPTs was panendoscopy. In more recent retrospective studies, other methods such as PET/CT were used, which makes it easier to detected SPTs in distant locations during follow-up. When we divided the studies by the time periods (1979-1998 vs 1999-2019), we observed that most of them were published during the last two decades and there was a difference in total percentages of SPTs (11.1\% vs $14.8 \%$ ) between the two time periods. The great difference in the number of patients is most likely due to the ease with which large patient registries can now be accessed and obviously the better diagnostic techniques. 


\section{4 | DISCUSSION}

It is known that HNC survivors have an increased morbidity and mortality risk compared with the healthy population and this relates to treatment sequelae, coexisting pulmonary, cardiac, and liver diseases as well as development of SPTs secondary to smoking and alcohol use. ${ }^{75}$ SPTs that often arise from the aerodigestive epithelium, are a major cause of mortality in HNC survivors. ${ }^{4}$ The criteria defining a SPT were established by Warren and Gates in $1932^{76}$ as follows: (a) both tumors are malignant; (b) the two cancers are anatomically separated by normal mucosa; and (c) the possibility that one tumor represents metastasis from the other is excluded. The index tumor is the first diagnosed tumor, and the SPT is any malignancy discovered thereafter. SPTs are classified as synchronous if they are diagnosed at the same time as the index tumor, for example, during staging of the index tumor, or within 6 months after discovery of the index tumor. If the SPT is discovered after a follow-up period of 6 months, it is classified as metachronous.

It is remarkable that the great majority of the patients in our review belong to retrospective studies from the last 20 years (more than 420000 patients). Given this fact, it is important to be aware of selection or other types of bias. Chuang et $\mathrm{al}^{62}$ performed a study to assess the risk of SPT and they calculated the standardized incidence ratios (SIRs). The number of SPTs observed was compared to the expected number of cancers to estimate the SIRs. For all cancer sites combined, the SIR of SPTs was 1.86 and the 20-year cumulative risk was $36 \%$. Lung cancer contributed the highest proportion of SPTs with a 20 -year cumulative risk of $13 \%$. They suggested that patients with HNCs are at increased risk of developing a SPT of the oral cavity and pharynx, esophagus, larynx and lung. Using SIRs is the most appropriate method for reporting the SPTs, but this methodology is used in only a few studies.

The follow-up time for patients included in this review is difficult to analyze as many studies do not provide data about the mean follow-up or only give a minimum follow-up times that patients should have in order to be included in the study. There were 20 articles given data about median follow-up. The median follow-up time is 4.6 years. However, as expected, for prospective studies the duration was shorter (2.6 years). As mentioned, these differences in follow-up periods could have influenced the reported rates of SPTs, as the incidence is cumulative between $3 \%$ and $7 \%$ per year. ${ }^{62}$

There are some articles in which the method used to detect SPTs is panendoscopy (bronchoscopy, esophagoscopy, direct laryngoscopy, and examination of the nasopharynx). Hujala et $\mathrm{al}^{59}$ reviewed 203 consecutive patients with HNC and reported a 3.9\% rate of synchronous SPTs. During the follow-up they found a $9.3 \%$ of metachronous SPTs. However, other authors including Hordijk et $\mathrm{al}^{41}$ have questioned the usefulness of this procedure given the small number of tumors it detects (between $1 \%$ and $2 \%$ ) and conclude that "panendoscopy should therefore be performed only as this diagnostic procedure is part of a well-documented prospective study." Dhooge et $\mathrm{al}^{48}$ analyzed the use of panendoscopy in patients treated with HNC to evaluate the usefulness of each of their procedures. They found a $3.4 \%$ rate of synchronous SPTs. They conclude that rigid bronchoscopy should not be performed if chest radiograph is normal. Also, they do not recommend esophagoscopy as a screening procedure in every HNC patients, and instead advocate direct orohypopharyngo-laryngoscopy. Rodriguez-Bruno et $\mathrm{al}^{66}$ suggested that routine panendoscopy should not be performed in nonsmoking patients since in their retrospective study of 64 patients synchronous SPTs were found in $12.1 \%$ of smoking patients and no synchronous SPTs were discovered in nonsmoking patients. Priante et $\mathrm{al}^{77}$ analyzed the efficacy of a single initial triple endoscopy in patients with HNC. The diagnosis of SPTs was more frequent in the intervention group than in a control group who underwent routine clinical examination. Although in the triple endoscopy group 50\% of the SPTs were diagnosed earlier, at the time of initial evaluation, there was no impact on prognosis. These conclusions should be taken with caution as the number of patients is very limited. It is important to realize that many studies report on a period with less advanced imaging techniques through which SPTs were not detected by imaging, but by panendoscopy. The importance and yield of panendoscopy were probably higher in the past than now following contemporary imaging in the diagnostic work-up. On the other hand, new endoscopic techniques, for example, narrow band imaging (NBI) ${ }^{78}$ may detect SPTs earlier, even as a synchronous instead of a metachronous tumor. Studies with image-enhanced endoscopy have shown very promising results in the detection of SPTs. Lugol's stain isolates abnormal mucosal islands within otherwise normal tissue, especially in the esophagus, enabling targeted biopsy. When combined with NBI, it is reported to have a sensitivity of $94.7 \%$ and a specificity of $90.4 \%$ to detect early stage esophageal lesions. ${ }^{79}$ Bugter el $\mathrm{al}^{80}$ carried out a systematic review on the diagnostic yield of Lugol chromoendoscopy for esophageal SPTs in patients with HNC, showing that on average, $15 \%$ of the patients with primary HNC that underwent Lugol chromoendoscopy were diagnosed with an esophageal-SPT, which compares favorably with the prevalence of retrospective nonscreening studies (1\%-6\%).

On the other hand, molecules such as DNAs, RNAs, proteins, metabolites, and microbiota, could be found in saliva. Therefore, salivary diagnostics has drawn significant 
attention for the detection of specific biomarkers of cancer Interestingly, salivary biomarkers signal not only for oral and pharyngeal disorders but also for tumors in different organs, suggesting that oral fluids may represent a substantial reservoir of molecular and microbial information, potentially useful to develop saliva-based biomarkers indicative of both local and systemic diseases. ${ }^{81,82}$

The location of the index tumor is an important factor, but its impact remains difficult to analyze due to the contradictory data found in the literature. Some authors have shown that the index tumor site is related to the risk of developing a SPT: Jones et $\mathrm{al}^{47}$ demonstrated that patients with oral cavity and oropharyngeal cancer had a significantly higher incidence of SPTs than patients with laryngeal or hypopharyngeal index tumors, as well as Haughey et $\mathrm{al}^{83}$ and Rafferty et al. ${ }^{53}$ Conversely, Patrucco and Aramendi, ${ }^{70}$ and Hujala et $a{ }^{59},{ }^{59}$ showed that the larynx is the location with the highest risk of developing a SPT. Within larynx, the greatest risk for SPTs is connected with supraglottic primary tumors, according to Leon et al. ${ }^{49}$ As the annual rate of SPTs in most studies is constant (between $3 \%$ and 5\%), the locations with the highest rate of cure will be those with a higher cumulative incidence of SPTs.

Review of the data suggests that the most frequent site of SPTs is the head and neck area, followed by the lung and then, the esophagus. Rafferty et $\mathrm{al}^{53}$ showed that the most common site, in their study of 425 patients, for the SPT was the oral cavity. They also found a high incidence of SPTs in the lungs. Jones et $\mathrm{al}^{47}$ found that the most common SPT site was the lung for patients with oropharyngeal, hypopharyngeal, and laryngeal index tumors. Schwartz et $\mathrm{al}^{46}$ discovered that the esophagus was the most frequent location for the synchronous SPT and the lung for the metachronous SPT. Within the head and neck area, the most frequent site for synchronous SPT was the pyriform sinus, and for the metachronous SPT the oral cavity. Hordijk et $\mathrm{al}^{27}$ as well as Black et $\mathrm{al}^{25}$ showed the majority of the SPTs were found in the head and neck region and lungs. Argiris et $\mathrm{al}^{5}$ found that the most frequent site of SPTs was the lungs, esophagus, and less frequently the head and neck.

Further, review of the literature reveals that SPTs is associated with a decreased overall survival. ${ }^{5,47-49,51,53}$ SPTs may arise at unfavorable sites like lungs or esophagus. Often, they arise in previously irradiated or operated areas. Therefore, the choice of treatment of the SPT may be influenced by the treatment of the index primary tumor. Because of prior therapy, the full range of treatment options may not be available (e.g., radiotherapy dose). Moreover, general condition of the patient with a newly diagnosed SPT can be severely compromised after the first treatment which can also explain why these tumors cannot always be treated according to accepted guidelines. $^{84,85}$

Argiris et $\mathrm{al}^{5}$ found that the causes of death in $324 \mathrm{HNC}$ patients from their study, were: treated malignant disease, treatment-associated acute or late complications, SPT, comorbidities (cardiac and respiratory illness) and unknown causes. The cumulative incidence of SPT was 5, 7, and $13 \%$ at 3, 5, and 10 years, respectively. Accordingly, Rennemo et $\mathrm{al}^{64}$ reported that 351 (17.0\%) of 2063 patients with HNC developed SPTs, and the overall survival rates of these patients were $40.0 \%$ at 5 years and $25.0 \%$ at 10 years, which were significantly lower than those in the non-SPT group $(P<.001)$, suggesting the need for early identification and management of SPTs to improve overall survival rates of these patients.

With this review we hope to raise awareness of the problem of SPTs in patients with HNC. Many areas remain understudied including the impact of HPV-related disease and the association with SPTs, the association between risk of SPTs and time from index primary tumor treatment and the role of continued diagnostic imaging in screening this high-risk population. By addressing these factors, a more evidence-based approach to follow-up strategies could be developed for patients with HNC.

\section{5 | CONCLUSIONS}

In this review, we found a mean rate of SPTs of $13.2 \%$ in patients treated for $\mathrm{HNC}$, with a great discrepancy between studies. As SPTs significantly affect the prognosis of HNC patients, follow-up of HNC patients should involve screening for SPTs. Since the head and neck area and the lung are the sites more frequently involved, follow-up should include a full head and neck examination including flexible laryngoscopy and consideration of chest imaging in high-risk groups.

\section{ORCID}

Andrés Coca-Pelaz (10) https://orcid.org/0000-0003-13638559

Juan P. Rodrigo (1) https://orcid.org/0000-0003-3063-0890 Alvaro Sanabria (1D https://orcid.org/0000-0002-5563-8840 Primož Strojan (10 https://orcid.org/0000-0002-0445-112X Carol R. Bradford (1) https://orcid.org/0000-0002-27684532

Ashok R. Shaha (1) https://orcid.org/0000-0001-7478-9436 Remco de Bree (1) https://orcid.org/0000-0001-7128-5814 Robert P. Takes (10) https://orcid.org/0000-0003-4784-0499

\section{REFERENCES}

1. Grégoire V, Lefebvre J-L, Licitra L, Felip E, EHNS-ESMOESTRO Guidelines Working Group. Squamous cell carcinoma 
of the head and neck: EHNS-ESMO-ESTRO Clinical Practice Guidelines for diagnosis, treatment and follow-up. Ann Oncol Off J Eur Soc Med Oncol. 2010;21:184-186.

2. Denaro N, Merlano MC, Russi EG. Follow-up in head and neck cancer: do more does it mean do better? A systematic review and our proposal based on our experience. Clin Exp Otorhinolaryngol. 2016;9:287-297.

3. Franco EL, Kowalski LP, Kanda JL. Risk factors for second cancers of the upper respiratory and digestive systems: a casecontrol study. J Clin Epidemiol. 1991;44:615-625.

4. Lippman SM, Hong WK. Second malignant tumors in head and neck squamous cell carcinoma: the overshadowing threat for patients with early-stage disease. Int J Radiat Oncol Biol Phys. 1989;17:691-694.

5. Argiris A, Brockstein BE, Haraf DJ, et al. Competing causes of death and second primary tumors in patients with locoregionally advanced head and neck cancer treated with chemoradiotherapy. Clin Cancer Res. 2004;10:1956-1962.

6. Lee DH, Roh J-L, Baek S, et al. Second cancer incidence, risk factor, and specific mortality in head and neck squamous cell carcinoma. Otolaryngol Head Neck Surg. 2013;149: 579-586.

7. Slaughter DP, Southwick HW, Smejkal W. Field cancerization in oral stratified squamous epithelium; clinical implications of multicentric origin. Cancer. 1953;6:963-968.

8. Sturgis EM, Miller RH. Second primary malignancies in the head and neck cancer patient. Ann Otol Rhinol Laryngol. 1995, 104:946-954.

9. Simcock R, Simo R. Follow-up and survivorship in head and neck cancer. Clin Oncol (R Coll Radiol). 2016;28:451-458.

10. Roman BR, Goldenberg D, Givi B, Education Committee of American Head and Neck Society (AHNS). AHNS series-do you know your guidelines? Guideline recommended follow-up and surveillance of head and neck cancer survivors. Head Neck. 2016;38:168-174.

11. León X, del Prado Venegas M, Orús C, López M, García J, Quer M. Influence of the persistence of tobacco and alcohol use in the appearance of second neoplasm in patients with a head and neck cancer. A case-control study. Cancer Causes Control. 2009;20:645-652.

12. Martel M, Alemany L, Taberna M, et al. The role of HPV on the risk of second primary neoplasia in patients with oropharyngeal carcinoma. Oral Oncol. 2017;64:37-43.

13. Morris LGT, Sikora AG, Patel SG, Hayes RB, Ganly I. Second primary cancers after an index head and neck cancer: subsitespecific trends in the era of human papillomavirus-associated oropharyngeal cancer. J Clin Oncol. 2011;29:739-746.

14. Adjei Boakye E, Buchanan P, Hinyard L, et al. Risk and outcomes for second primary human papillomavirus-related and -unrelated head and neck malignancy. Laryngoscope. 2019;129: 1828-1835.

15. Shamseer L, Moher D, Clarke M, et al. Preferred reporting items for systematic review and meta-analysis protocols (PRISMA-P) 2015: elaboration and explanation. BMJ. 2015;350:g7647.

16. Weichert KA, Schumrick D. Multiple malignancies in patients with primary carcinomas of the head and neck. Laryngoscope. 1979;89:988-991.

17. Vrabec DP. Multiple primary malignancies of the upper aerodigestive system. Ann Otol Rhinol Laryngol. 1979;88:846-854.
18. Gluckman JL. Synchronous multiple primary lesions of the upper aerodigestive system. Arch Otolaryngol. 1979;105:597-598.

19. Weaver A, Fleming SM, Knechtges TC, Smith D. Triple endoscopy: a neglected essential in head and neck cancer. Surgery. 1979;86:493-496.

20. Shapshay SM, Hong WK, Fried MP, Sismanis A, Vaughan CW, Strong MS. Simultaneous carcinomas of the esophagus and upper aerodigestive tract. Otolaryngol Head Neck Surg. 1980;88:373-377.

21. Maisel RH, Vermeersch H. Panendoscopy for second primaries in head and neck cancer. Ann Otol Rhinol Laryngol. 1981;90: 460-464.

22. Atkinson D, Fleming S, Weaver A. Triple endoscopy. A valuable procedure in head and neck surgery. Am J Surg. 1982;144: 416-419.

23. Deviri E, Bartal A, Goldsher M, Eliachar I, Steinitz R, Robinson E. Occurrence of additional primary neoplasms in patients with laryngeal carcinoma in Israel (1960-1976). Ann Otol Rhinol Laryngol. 1982;91:261-265.

24. McGuirt WF. Panendoscopy as a screening examination for simultaneous primary tumors in head and neck cancer: a prospective sequential study and review of the literature. Laryngoscope. 1982;92:569-576.

25. Black RJ, Gluckman JL, Shumrick DA. Multiple primary tumours of the upper aerodigestive tract. Clin Otolaryngol Allied Sci. 1983;8:277-281.

26. Grossman TW, Toohill RJ, Lehman RH, Duncavage JA, Malin TC. Role of esophagoscopy in the evaluation of patients with head and neck carcinoma. Ann Otol Rhinol Laryngol. 1983;92:369-372.

27. Hordijk GJ, de Jong JM. Synchronous and metachronous tumours in patients with head and neck cancer. J Laryngol Otol. 1983;97:619-621.

28. Atkins JP, Keane WM, Young KA, Rowe LD. Value of panendoscopy in determination of second primary cancer. A study of 451 cases of head and neck cancer. Arch Otolaryngol. 1984; 110:533-534.

29. Leipzig B, Zellmer JE, Klug D. The role of endoscopy in evaluating patients with head and neck cancer. A multi-institutional prospective study. Arch Otolaryngol. 1985;111:589-594.

30. de Vries N, Van der Waal I, Snow GB. Multiple primary tumours in oral cancer. Int J Oral Maxillofac Surg. 1986;15:85-87.

31. Lau WF, Siu KF, Wei W, Lam KH. Prospective screening for multiple tumors of the upper aerodigestive tract: a simple routine procedure. Laryngoscope. 1986;96:1149-1153.

32. Lundgren J, Olofsson J. Multiple primary malignancies in patients treated for laryngeal carcinoma. J Otolaryngol. 1986; 15:145-150.

33. Schuller DE, Fritsch MH. An assessment of the value of triple endoscopy in the evaluation of head and neck cancer patients. J Surg Oncol. 1986;32:156-158.

34. Shikhani AH, Matanoski GM, Jones MM, Kashima HK, Johns ME. Multiple primary malignancies in head and neck cancer. Arch Otolaryngol Head Neck Surg. 1986;112:1172-1179.

35. Shibuya H, Hisamitsu S, Shioiri S, Horiuchi J, Suzuki S. Multiple primary cancer risk in patients with squamous cell carcinoma of the oral cavity. Cancer. 1987;60:3083-3086.

36. Masaki N, Hashimoto T, Ikeda H, Inoue T, Kozuka T. Multiple primary malignancies in patients with head and neck cancer. Jpn J Clin Oncol. 1987;17:303-307. 
37. Poppendieck J. Incidence of multiple tumors in the upper aerodigestive tract. Routine panendoscopy? HNO. 1987;35: 19-23.

38. Parker JT, Hill JH. Panendoscopy in screening for synchronous primary malignancies. Laryngoscope. 1988;98:147-149.

39. Poppendieck J, Schrader M. Improved diagnosis of second carcinomas by routine panendoscopy. Adv Otorhinolaryngol. 1988; 39:111-119.

40. Shaha A, Hoover E, Marti J, Krespi Y. Is routine triple endoscopy cost-effective in head and neck cancer? Am J Surg. 1988; 155:750-753.

41. Hordijk GJ, Bruggink T, Ravasz LA. Panendoscopy: a valuable procedure? Otolaryngol Head Neck Surg. 1989;101:426-428.

42. Panosetti E, Luboinski B, Mamelle G, Richard JM. Multiple synchronous and metachronous cancers of the upper aerodigestive tract: a nine-year study. Laryngoscope. 1989;99: 1267-1273.

43. Panosetti E, Arnold W, Müller W. Site and incidence of multiple cancers in patients with squamous cell carcinomas of the upper aerodigestive tract. Laryngorhinootologie. 1990;69:449-453.

44. Choy AT, van Hasselt CA, Chisholm EM, Williams SR, King WW, Li AK. Multiple primary cancers in Hong Kong Chinese patients with squamous cell cancer of the head or neck. Cancer. 1992;70:815-820.

45. Esteller Moré E, Quer Agusti M, Burgues Vila J, Viladot Castells J, López-Pousa A, Vega M. Synchronous carcinomas of the upper aerodigestive tract: a diagnostic and therapeutic problem. Acta Otorrinolaringol Esp. 1992;43:329-334.

46. Schwartz LH, Ozsahin M, Zhang GN, et al. Synchronous and metachronous head and neck carcinomas. Cancer. 1994;74: 1933-1938

47. Jones AS, Morar P, Phillips DE, Field JK, Husband D, Helliwell TR. Second primary tumors in patients with head and neck squamous cell carcinoma. Cancer. 1995;75:13431353.

48. Dhooge IJ, De Vos M, Albers FW, Van Cauwenberge PB. Panendoscopy as a screening procedure for simultaneous primary tumors in head and neck cancer. Eur Arch Otorhinolaryngol. 1996;253:319-324.

49. León X, Quer M, Diez S, Orús C, López-Pousa A, Burgués J. Second neoplasm in patients with head and neck cancer. Head Neck. 1999;21:204-210.

50. Esposito ED, Bevilacqua L, Guadagno MT. Multiple primary malignant neoplasm in patients with laryngeal carcinoma. J Surg Oncol. 2000;74:83-86.

51. Nikolaou AC, Markou CD, Petridis DG, Daniilidis IC. Second primary neoplasms in patients with laryngeal carcinoma. Laryngoscope. 2000;110:58-64.

52. Albright JT, Karpati R, Topham AK, Spiegel JR, Sataloff RT. Second malignant neoplasms in patients under 40 years of age with laryngeal cancer. Laryngoscope. 2001;111:563-567.

53. Rafferty MA, O'Dwyer TP. Secondary primary malignancies in head and neck squamous cell carcinoma. J Laryngol Otol. 2001; 115:988-991.

54. Stoeckli SJ, Zimmermann R, Schmid S. Role of routine panendoscopy in cancer of the upper aerodigestive tract. Otolaryngol Head Neck Surg. 2001;124:208-212.

55. Spector JG, Sessions DG, Haughey BH, et al. Delayed regional metastases, distant metastases, and second primary malignancies in squamous cell carcinomas of the larynx and hypopharynx. Laryngoscope. 2001;111:1079-1087.

56. Holland JM, Arsanjani A, Liem BJ, Hoffelt SC, Cohen JI, Stevens KR. Second malignancies in early stage laryngeal carcinoma patients treated with radiotherapy. J Laryngol Otol. 2002; 116:190-193.

57. Gao X, Fisher SG, Mohideen N, Emami B. Second primary cancers in patients with laryngeal cancer: a population-based study. Int J Radiat Oncol Biol Phys. 2003;56:427-435.

58. Warnakulasuriya KAAS, Robinson D, Evans H. Multiple primary tumours following head and neck cancer in southern England during 1961-98. J Oral Pathol Med. 2003;32:443-449.

59. Hujala K, Sipilä J, Grenman R. Panendoscopy and synchronous second primary tumors in head and neck cancer patients. Eur Arch Otorhinolaryngol. 2005;262:17-20.

60. Alvarez Marcos CA, Llorente Pendás JL, Franco Gutiérrez V, et al. Second primary tumors in head and neck cancer. Acta Otorrinolaringol Esp. 2006;57:462-466.

61. Sjögren EV, Snijder S, van Beekum J, Baatenburg de Jong RJ. Second malignant neoplasia in early (TIS-T1) glottic carcinoma. Head Neck. 2006;28:501-507.

62. Chuang S-C, Scelo G, Tonita JM, et al. Risk of second primary cancer among patients with head and neck cancers: a pooled analysis of 13 cancer registries. Int J Cancer. 2008;123:2390-2396.

63. López Mollá C, Estellés Ferriol E, Carrasco Llatas M, Seijas Rosales T, Morales Suárez-Varela M, Dalmau Galofre J. Malignant multiple neoplasms in head and neck squamous cell carcinoma. Acta Otorrinolaringol Esp. 2008;59:427-432.

64. Rennemo E, Zätterström U, Boysen M. Impact of second primary tumors on survival in head and neck cancer: an analysis of 2,063 cases. Laryngoscope. 2008;118:1350-1356.

65. Morris LGT, Sikora AG, Hayes RB, Patel SG, Ganly I. Anatomic sites at elevated risk of second primary cancer after an index head and neck cancer. Cancer Causes Control. 2011;22:671-679.

66. Rodriguez-Bruno K, Ali MJ, Wang SJ. Role of panendoscopy to identify synchronous second primary malignancies in patients with oral cavity and oropharyngeal squamous cell carcinoma. Head Neck. 2011;33:949-953.

67. Jégu J, Binder-Foucard F, Borel C, Velten M. Trends over three decades of the risk of second primary cancer among patients with head and neck cancer. Oral Oncol. 2013;49:9-14.

68. Krishnatreya M, Rahman T, Kataki AC, Das A, Das AK, Lahkar K. Synchronous primary cancers of the head and neck region and upper aero digestive tract: defining high-risk patients. Indian J Cancer. 2013;50:322-326.

69. Tiwana MS, Hay J, Wu J, Wong F, Cheung W, Olson RA. Incidence of second metachronous head and neck cancers: population-based outcomes over 25 years. Laryngoscope. 2014;124:2287-2291.

70. Patrucco MS, Aramendi MV. Prognostic impact of second primary tumors in head and neck cancer. Eur Arch Otorhinolaryngol. 2016;273:1871-1877.

71. Adeel M, Siddiqi MI. Metachronous second primary malignancy in head and neck cancer patients: is five years of follow-up sufficient? J Korean Assoc Oral Maxillofac Surg. 2018;44:220-224.

72. Adjei Boakye E, Buchanan P, Hinyard L, Osazuwa-Peters N, Schootman M, Piccirillo JF. Incidence and risk of second primary malignant neoplasm after a first head and neck squamous cell carcinoma. JAMA Otolaryngol Head Neck Surg. 2018; 144:727-737. 
73. Leoncini E, Vukovic V, Cadoni G, et al. Tumour stage and gender predict recurrence and second primary malignancies in head and neck cancer: a multicentre study within the INHANCE consortium. Eur J Epidemiol. 2018;33:1205-1218.

74. Silén S, Haapaniemi A, Dickinson A, Rönn K, Mäkitie A. Presentation of second primary cancers in young laryngeal carcinoma patients. Acta Otolaryngol. 2019;139:85-89.

75. Hall SF, Groome PA, Rothwell D. The impact of comorbidity on the survival of patients with squamous cell carcinoma of the head and neck. Head Neck. 2000;22:317-322.

76. Warren S, Gates O. Multiple malignant tumors: a survey of literature and statistical study. Am J Cancer. 1932;16:1358-1414.

77. Priante AVM, Gross JL, Sztokfisz CZ, Nishimoto IN, Kowalski LP. Diagnosis of second primary tumor and long-term survival after single initial triple endoscopy in patients with head and neck cancer. Eur Arch Otorhinolaryngol. 2014;271:2285-2292.

78. Tirelli G, Piovesana M, Bonini P, Gatto A, Azzarello G, Boscolo Nata F. Follow-up of oral and oropharyngeal cancer using narrowband imaging and high-definition television with rigid endoscope to obtain an early diagnosis of second primary tumors: a prospective study. Eur Arch Otorhinolaryngol. 2017;274:2529-2536.

79. Wang C-H, Lee Y-C, Wang C-P, et al. Use of transnasal endoscopy for screening of esophageal squamous cell carcinoma in high-risk patients: yield rate, completion rate, and safety. Dig Endosc. 2014;26:24-31.

80. Bugter O, van de Ven SEM, Hardillo JA, Bruno MJ, Koch AD, Baatenburg de Jong RJ. Early detection of esophageal second primary tumors using Lugol chromoendoscopy in patients with head and neck cancer: a systematic review and meta-analysis. Head Neck. 2019;41:1122-1130.

81. Arantes LMRB, De Carvalho AC, Melendez ME, Lopes Carvalho A. Serum, plasma and saliva biomarkers for head and neck cancer. Expert Rev Mol Diagn. 2018;18:85-112.

82. Wang X, Kaczor-Urbanowicz KE, Wong DTW. Salivary biomarkers in cancer detection. Med Oncol. 2017;34:7.

83. Haughey BH, Gates GA, Arfken CL, Harvey J. Meta-analysis of second malignant tumors in head and neck cancer: the case for an endoscopic screening protocol. Ann Otol Rhinol Laryngol. 1992;101:105-112.

84. van der Waal I, de Bree R. Second primary tumours in oral cancer. Oral Oncol. 2010;46:426-428.

85. Strojan P, Corry J, Eisbruch A, et al. Recurrent and second primary squamous cell carcinoma of the head and neck: when and how to reirradiate. Head Neck. 2015;37:134-150.

How to cite this article: Coca-Pelaz A, Rodrigo JP, Suárez C, et al. The risk of second primary tumors in head and neck cancer: A systematic review. Head \& Neck. 2020;42:456-466. https://doi.org/10.1002/hed.26016 